\title{
INTERACADEMY COUNCIL/IAP- THE GLOBAL NETWORK OF SCIENCE ACADEMIES, 2012 Responsible Conduct in the Global Research Enterprise: A Policy Report
}

Este documento parte de la convicción de que existe algo así como un sistema global de investigación científica. Se supone que es un sistema social amplio, laxamente integrado, pero compuesto por investigadores, patrocinadores, beneficiarios, reguladores y participantes (cuando se trata de investigación con sujetos humanos). Las academias de ciencias suelen sostener relaciones protocolares y emitir, de vez en cuando, documentos ilustrativos de su trabajo, empeños y logros.

Este documento sirve, o debiera servir, como guía para recordar los valores básicos involucrados en la práctica de la investigación científica. La principal conclusión, como cabía esperar, es que son los investigadores quienes tienen la responsabilidad primaria en relación a lo que en la jerga corriente ha venido a llamarse "conducta responsable en investigación". No debe olvidarse, sin embargo, que el énfasis individualista puede no ser un carácter universal de las relaciones sociales en algunas culturas.

Las instituciones de investigación, por su parte, tienen la obligación de producir y publicar normas claras de comportamiento. Las denuncias sobre irregularidades son, de nuevo, materia de difícil regulación universal, pero muchas de las fallas que se observan en la literatura no dependen necesariamente de las personas. También las instituciones, por la cultura organizacional y el clima que mantienen, son responsables de la calidad del trabajo.

Otros grupos interesados en la transparencia y calidad de los procesos y productos de la investigación se relacionan con quienes la financian. No está de más recordar algunos vicios frecuentes. Por ejemplo, el énfasis en lo cuantitativo sobre lo cualitativo, la renuencia a publicar resultados negativos o la tentación de ocultar informaciones que pueden producir perjuicios económicos a los patrocinadores. La integridad es un valor, no por popular muy difundido y es difícil dictar reglas cuando hay fuertes inversiones de por medio.

Como la mayoría de las investigaciones termina en productos escritos, ya sea en papel o en formatos electrónicos, son los editores quienes tienen algo que decir sobre la calidad final del producto. Un vicio frecuente es publicar varias veces lo mismo. Plagiar estudios ya realizados no es tan raro como pudiera creerse. Y está también la viciosa costumbre de ampliar el factor de impacto de las publicaciones estimulando las citas.

Aunque el informe no se extiende sobre el tema, el creciente abuso de la publicación "open access" es un tema que debe preocupar a la comunidad científica. No hay semana en que no lleguen invitaciones a publicar en revistas electrónicas de las que nadie sabe siquiera si existen en alguna parte de la Tierra o se trata solamente de algún aventurero o aventurera que, con computador y servidor, dice tener un "journal" acreditado. Como está asociado a pago por parte de los autores, este tipo de publicación conduce a un "clientelismo" peor que el que sostenía a los grandes imperios editoriales basados en la propaganda de la industria. Pues ahora cualquier ciudadano con dinero puede, teóricamente, llegar con sus publicaciones a todo el mundo. Hay hasta perversos incentivos relacionados con la celeridad con que se saldrá a la circulación pública, pues algunas publicaciones virtuales ofrecen menos de dos semanas de "revisión" antes de salir al mercado de las ideas y los datos.

Aparte la muy compleja noción de la globalización del sistema social de la investigación tecnocientí- 
fica, poco hay de novedad en este informe. Se trata, no obstante, de esos documentos de consulta y citación indispensables para quienes deseen entrenar o ser entrenados en el arte de producir ciencia.

Fernando Lolas Stepke

\section{PIETRO MAGLIOZZI, M.I}

\section{El arte de sanar}

Ed. San pablo, 230 pp.

“-Es muy connatural-dijo Critilo- en el hombre la inclinación a su Dios, como a su principio y a su fin, ya amándole, ya conociéndole. No se ha hallado nación, por bárbara que fuese, que no haya reconocido la divinidad, por que en la naturaleza no hay cosa de valde ni inclinación que se frustre. Si el imán busca el norte, sin duda que le hay donde se quiete; si la planta al sol, el pez al agua, la piedra al centro y el hombre a Dios, Dios hay que es su norte, centro y sol a quien busque, en quien pare y a quien goze" ${ }^{\text {. }}$

Efectivamente, el ser humano posee un sentido de trascendencia espiritual que lo diferencia de las demás especies, expresado principalmente a través de las religiones monoteístas, las cuales representan un grado mayor de evolución cultural. Hasta la neurociencia ha demostrado, con base imagineológica, que aquellas personas sometidas a estímulos dolorosos o situaciones de alto estrés toleran distinto, en sentido positivo, los estímulos negativos, cuando son acompañados por evocaciones concernientes a sus creencias religiosas, por ejemplo: oraciones, determinadas imágenes o himnos sacros.

Ya ni empeño hay en discutir que el cuerpo puede enfermar al espíritu y, asimismo, las tribulaciones del alma pueden esmaltar al cuerpo, somatizándolo. Ante esta realidad, la fe es, sin duda, una fuente de esperanza, remanso de resignación, quietud, paciencia y descanso espiritual.

En esa línea, el libro del Dr. Pietro Magliozzi es una oportunidad, no sólo para aquel que profesa la religión católica, sino para todos aquellos en búsqueda de una respuesta o de un buen comienzo que conduzca a la sanación del alma.

Ciertamente, el principal guía espiritual que nos propone el autor es Cristo Médico, quien conduce en sus brazos al enfermo en sus afectos, con su manto protector, durante todo su personal "Getsemani".

El ámbito de la fe envuelve la atmósfera que rodea al afligido, invitándolo a la introspección más auténtica, aquella que remueve las entrañas de los afectos, la conciencia y el sentido de nuestra existencia. Para ello, el autor nos propone un ejercicio volitivo-intelectual y espiritual, el cual, a través de la oración, la programación neurolingüística y la reflexión, nos otorga la esperanza de llegar en primer término a la auto-aceptación, al perdón de nuestras propias faltas y debilidades, a la adecuada imagenidentidad de nosotros mismos, en un proceso que involucra el análisis desde el apego, en la díada madre-hijo e incluso antes, ya en el claustro materno, cuando comenzamos a elaborar nuestra percepción del yo. Para luego, desde nosotros mismos, volcar la mirada empática hacia el otro, aprendiendo a perdonar a nuestros semejantes, idénticos en naturaleza y creación, alejando el rencor, la envidia, los pecados, que tanto pesan, en lo que constituye el proceso de "sanación interior".

María Isabel Cornejo Plaza

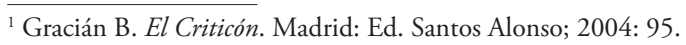

